\title{
A preliminary evaluation of effects of high doses of Jujube and Saffron on biochemical and hematological parameters in rats
}

\author{
Banafsheh Safizadeh, Reyhane Hoshyar ${ }^{*}$, Mina Hemmati, Asghar Zarban and Roshanak Ebrahimi*
}

\begin{abstract}
We investigated effects of high doses of Jujube fruits and Saffron petals on biochemical and hematological biomarkers in rats. During 14 days treatment of herbs, mortality was not observed. No difference reported in FBS, lipid profile, total protein, albumin, total bilirubin and hematological parameters of rats after treatments. BUN, cratinine, urate and liver enzymes levels in both extracts increased. These changes were more noticeable in Saffron compared with Jujube. This study can suggest that administration of high doses of Jujube (up $5000 \mathrm{mg} / \mathrm{kg}$ ) and Saffron (up $2000 \mathrm{mg} / \mathrm{kg}$ ) are nearly safe, also did not exert hepato and nephrotoxicity in rats.
\end{abstract}

Keywords: Saffron, Jujube, Liver enzymes, Hematological parameters, In vivo

\section{Findings}

This investigation was supported by Grant No. 1000 from the office of Vice Chancellor for Research, Birjand University of Medical Sciences.

\section{Background}

Medicinal plants have commonly been used for different diseases, such as Alzheimer [1], atherosclerosis [2], diabetes mellitus [3], cancer [4] and gastrointestinal diseases [5]. Although these plants are considered to be organic and safe, however may cause damage due to their unwanted side effects [6]. Therefore, studying effects of high doses of medicinal plants would have effective role in identifying of their safety profile in humans [7].

Ziziphus jujube M. (Jujube, J) and Crocus sativus L, (Saffron, S) belonging to the Rhamnaceous and Iridaceae families respectively [8]. These herbs grows mostly in southern and eastern Asia, especially Iran [9]. Saffron petal is a by-product of saffron and is usually discarded as a waste [10]. Recently it has been reported multiple biological effects of both herbs including antioxidant, anti-inflammatory, anti-cancer and regulating of blood sugar and lipid [11]. Like other plants, Saffron petals and Jujube fruits contained chemical components such as

\footnotetext{
* Correspondence:

reyhaneh.houshyar@gmail.com; roshanak.ebrahimi@ymail.com

Department of Biochemistry, School of Medicine, Birjand University of Medical Sciences, P.O. Box: 9717853577, Birjand, Iran
}

$\mathrm{H}_{2} \mathrm{O}$, carbohydrates, lipids, proteins and minerals and many bioactive compounds including triterpenic acids, flavonoids, cerebrosides, phenolic acids, $\alpha$-tocopherol, $\beta$-carotene [12].

Firstly it is essential to investigate toxic doses of herbs in animal model to avoid potential harmful effects when used as medicine. This study evaluated properties of Saffron petals and Jujube fruits on their high dosesinduced changes in blood biochemical markers in rats.

\section{Methods}

\section{Preparation of plant extracts}

Fresh-ripended fruits of Jujube and petals of Saffron were collected from Birjand, South Khorassan, Iran from September to October, 2014. These were dried in shadow then ground with a grinder (Hamilton Beach Brand, Canada). Aqueous extracts were prepared using $5 \mathrm{~g}$ of dried powder in $100 \mathrm{ml}$ of boiling water for $2 \mathrm{~h}$. The mixtures were filtered through a No. 1 Whatman filter paper and thus oven-dried at $40{ }^{\circ} \mathrm{C}$ for $24 \mathrm{~h}$. Eventually, the samples lyophilized by freezing at $-80{ }^{\circ} \mathrm{C}$ for $24 \mathrm{~h} \mathrm{[13].} \mathrm{The} \mathrm{crude} \mathrm{extracts} \mathrm{were} \mathrm{dissolved} \mathrm{in} \mathrm{distilled}$ water just prior to oral administration. Each extract was administered in five doses equal to 150, 500, 1000, 2000 and $5000 \mathrm{mg} / \mathrm{kg}$ body weight. The voucher number of specimen for Saffron (H. No. 2669) and for Jujube (H. No. 2470) was deposited in the Herbarium of Birjand University, Iran.

\section{Springer Open}


Ferric Reducing Antioxidant Power (FRAP) assay

The total antioxidant capacity of herbal extracts was determined by FRAP assay [14]. The results were expressed in MFe (II)/g dry weight of plant extracts (DW).

\section{Folin-Ciocalteu assay}

The total phenolic contents of herbal extracts were measured using the Folin Ciocalteu method [15]. The data were expressed as milligram Gallic acid equivalents (GAE)/g dried weight of plant extracts (DW).

\section{Determination of Total monomeric anthocyanins (TMA)}

The TMA have been estimated by a $\mathrm{pH}$ differential method [16] using UV-Vis spectrophotometer. Results were expressed as $\mathrm{mg}$ of cyanidin-3-glucoside equivalents per liter of herbal extracts.

\section{Animal experiments}

Male Wistar rats (6-8-old-week; $200 \pm 20$ g) were purchased from animal house of Birjand University of Medical Sciences, Iran. All animal procedures were approved by the Animal Ethical Committee in accordance with the Guidelines for the Care and Use of Laboratory Animals prepared by this university. Rats were individually housed in a thermally controlled $\left(25 \pm 2{ }^{\circ} \mathrm{C}\right)$ room free from any sources of chemical contamination. Light was maintained on a $12 \mathrm{~h}$ dark-light cycle, and rats were fed a standard laboratory diet of rat chow (Javaneh Khorasan Co, Mashhad, Iran) with free access to tap water.

\section{Study design}

Animals were acclimatized to the laboratory conditions for the duration of ten days before the commencement of the experiment. 77 Rats were randomly assigned to 11 groups $(n=7 /$ cage) and were weighed weekly. Experimental groups J1 and S1, J2 and S2, J3 and S3, J4 and S4 and J5 and S5 were received extracts at 150, 500, 1000, 2000 and $5000 \mathrm{mg} / \mathrm{kg}$ by gavage, respectively, for 14 days. Healthy control group $(\mathrm{C})$ was gavaged with normal saline during this period. The used doses of herbs were based on Ahmad study [17].

\section{Sample preparation}

At the end of study blood was collected in sterile vial with and without anticoagulant for whole blood and serum separation respectively.

\section{Hematology analysis}

Red Blood Cells (RBC), Hemoglobin (Hb), Packed Cell Volume (PCV), Total White Blood Cells (WBC), Leukocyte Count (DLC) and thrombocyte count was estimated using an automated blood analyzer (Cell Dyn`3700, Abbott Dignostic, USA).

\section{Biochemical analysis}

Sera samples were analyzed for biochemical parameters such as Fasting Blood Suger (FBS), lipid profile (cholesterol, triglyceride, LDL, HDL), total protein, albumin, total bilirubin, using standard commercial kits (Pars Azmoon, Tehran, Iran).

\section{Assessment of liver function}

Serum Alanine Amino Teransferases (ALT/SGPT), Aspartate Amino Teransferases (AST/SGOT), Lactate Dehydrogenase (LDH), Alkaline Phosphatase (ALP), were determined to check the function of liver.

\section{Assessment of kidney function}

Blood Urea Nitrogen (BUN), cratinine and uric Acid using standard commercial kits (Pars Azmoon, Tehran, Iran) were evaluated to control the function of kidneys.

\section{Statistical analysis}

Results were expressed as the mean \pm SD of the indicated number of independent experiments. The Student$T$ test was used to compare the mean values of different parameters obtained in various groups by employing SPSS (version 18) software and $P<0.05$ were considered as significant.

\section{Results}

Total antioxidant activity (TAA)

The FRAP values of adequate concentrations of both extracts $(2.5 \mathrm{~g} / \mathrm{l})$ indicated in Table 1 . Total antioxidant activity expressed in $\mathrm{M} \mathrm{Fe}(\mathrm{II})$ per gram dry weight (DW) of plant extracts.

\section{Total phenolics contents (TPC)}

The results of total phenolic values of herbs $(2.5 \mathrm{~g} / \mathrm{l})$ are presented in Table 1. Total phenol content expressed in milligrams of Gallic acid equivalents (GAE) per gram dried weight (DW) of plant extracts.

\section{Total anthocyanins contents (TAC)}

Total monomeric anthocyanins of extracts are shown in Table 1. Total monomeric anthocyamins expressed as mg cy-3-glu per liter of plant extracts.

\section{Effects of herbs on rat's survival and body weight}

The results revealed that no significant differences in survival were observed between groups, with approximately $98 \%$ of the animals surviving to study termination. Table 2 showed the changes in weight of all animals during the experiment as well as the lower weight of animals in the 55 -treated group. The mean body weights of rats receiving J1-J5 and S1-S5 did not significantly $(P<0.05)$ differ from controls (Group $C)$ over time. 
Effects of herbs on hematological parameters

Our data illustrated that treated rats (Groups J1-J5 and S1-S5) did not exhibited significant difference in RBC, $\mathrm{Hb}$ and $\mathrm{PCV}$, platelet, lymphocytes and neutrophils levels when compared to healthy rats (group C). In the other words the herbal treated rats showed normal values of $\mathrm{CBC}$ count after treatments.

\section{Effects of herbs on serum biochemical parameters}

Based on biochemical analysis, herbs didn't have any effect on FBS and lipid profile as compared to the control group. Also concentrations of total bilirubin, total protein and albumin in treated sera with all of doses of Jujube are similar to healthy samples (Table 3a). At the same time, the decrease in total protein and albumin levels and the increase in total bilirubin induced by 2000 and $5000 \mathrm{mg} / \mathrm{kg}$ Saffron were significantly observed when compared to control (Table 3b).

\section{Effects of herbs on serum hepatic enzymes}

Results revealed that treatment with J4, J5, S3, S4 and S5 caused a significant increase ( $p<0.05$ vs controls) in serum concentrations of liver enzymes (Table 4 ).

\section{Effects of herbs on renal biomarkers}

Groups-J5, S4, S2 rats showed a significant $(P<0.05)$ increase in BUN, cratinine and uric acid levels in comparison to control rats. Whereas other treated rats showed normal levels of these factors (Table 5).

\section{Discussion}

Recently herbal medicine has attracted great attention and is increasingly applied as alternatives to chemical drugs. Certain factors contributed to their importance including effectiveness, availability, affordability, apparently and safety activities [18]. In spite of great therapeutic ability of herbs they may have side effects in their toxic doses [19]. Therefore, before using any herbal extraction it should be evaluated its toxic effects on various organs of body such as liver, kidney and blood. There have been a few reports on possible toxicological properties of Saffron petals and Jujube fruits [20]. This study aimed to investigate effects of high concentrations of these plants on functions of liver and kidney in rats.

Table 1 The total antioxidant activity, total phenolics and total anthocyanins of both extracts

\begin{tabular}{llr}
\hline Antioxidant content & Jujube fruit & Saffron petal \\
\hline TAA (M Fe(II)/g DW) & $350.63 \pm 6.25$ & $442 \pm 5.87$ \\
TPC (GAE/g DW) & $210 \pm .2 .66$ & $294 \pm 3.33$ \\
TAC (mg cy-3-glu/l) & $504.65 \pm 7.12$ & $610.22 \pm 8.32$ \\
\hline
\end{tabular}

Data are expressed as mean $\pm \mathrm{SD}(n=3)$
Table 2 Effects of herbs on body weight of rats

\begin{tabular}{lclc}
\hline $\begin{array}{l}\text { Experimental } \\
\text { groups }^{\mathrm{a}}\end{array}$ & $\begin{array}{l}\text { Body weight } \\
\text { change (\%) }\end{array}$ & $\begin{array}{l}\text { Experimental } \\
\text { groups }\end{array}$ & $\begin{array}{l}\text { Body weight } \\
\text { change (\%) }\end{array}$ \\
\hline Healthy Control & $5.63 \pm 0.25^{\mathrm{b}}$ & Healthy Control & $5.63 \pm 0.25$ \\
$J 1(150 \mathrm{mg} / \mathrm{kg})$ & $5.85 \pm .21$ & $\mathrm{~S} 1(150 \mathrm{mg} / \mathrm{kg})$ & $5.79 \pm 0.21$ \\
$J 2(500 \mathrm{mg} / \mathrm{kg})$ & $5.65 \pm 0.1$ & $\mathrm{~S} 2(500 \mathrm{mg} / \mathrm{kg})$ & $5.65 \pm 0.1$ \\
$J 3(1000 \mathrm{mg} / \mathrm{kg})$ & $5.61 \pm 0.2$ & $\mathrm{~S} 3(1000 \mathrm{mg} / \mathrm{kg})$ & $5.63 \pm 0.2$ \\
$J 4(2000 \mathrm{mg} / \mathrm{kg})$ & $5.65 \pm 0.3$ & $\mathrm{~S} 4(2000 \mathrm{mg} / \mathrm{kg})$ & $5.55 \pm 0.3$ \\
$J 5(5000 \mathrm{mg} / \mathrm{kg})$ & $5.71 \pm .2$ & $\mathrm{~S} 5(5000 \mathrm{mg} / \mathrm{kg})$ & $5.01 \pm 0.2^{*}$
\end{tabular}

${ }^{\mathrm{a}}$ For details of experimental conditions see the text

${ }^{b}$ Data are expressed as mean \pm SD of 8 rats in each group (In each column) *was considered significant at $P<0.05$ when compared with the healthy control group

Also the antioxidant properties of aqueous extracts of Jujube and Saffron were evaluated.

A complete picture of total antioxidants capacity of both extracts determined was obtained via analysis by FRAP and Ciocalteu assays. The results showed that the Saffron petals extract has a higher content in total antioxidants and total phenolices than Jujube fruit extract. The anthocyanins amount was also determined by spectrophotometry. It was found that Saffron petals were richer in anthocyanins compared to Jujube fruits.

Liver is a vital organ in body that regulated various metabolic and detoxification pathways. Excretion of most toxicants and their metabolites is by way of the kidneys, So liver or kidney injuries induced by common agents such as drugs or organic components have serious outcomes in body. Various studies were reported

Table 3 Effects of herbs on general biochemical parameters in serum of rats

\begin{tabular}{llll}
\hline $\begin{array}{l}\text { Experimental } \\
\text { groups }^{\mathrm{a}}\end{array}$ & $\begin{array}{l}\text { Total protein } \\
(\mathrm{g} / \mathrm{dl})\end{array}$ & $\begin{array}{l}\text { Albumin } \\
(\mathrm{g} / \mathrm{dl})\end{array}$ & $\begin{array}{l}\text { Total bilirubin } \\
(\mathrm{mg} / \mathrm{dl})\end{array}$ \\
\hline $\begin{array}{l}\text { a. Jujube } \\
\text { Healthy Control }\end{array}$ & $8.68 \pm 0.6^{\mathrm{b}}$ & $4.88 \pm 0.7$ & $0.85 \pm 0.1$ \\
J1 $(150 \mathrm{mg} / \mathrm{kg})$ & $8.65 \pm 0.5$ & $4.91 \pm 0.2$ & $0.88 \pm 0$ \\
J2 $(500 \mathrm{mg} / \mathrm{kg})$ & $8.63 \pm 0.3$ & $4.87 \pm 0.4$ & $0.90 \pm 0$ \\
J3 (1000 mg/kg) & $8.62 \pm 0.6$ & $4.90 \pm 0.2$ & $0.87 \pm 0.2$ \\
J4 (2000 mg/kg) & $8.61 \pm 0.8$ & $4.83 \pm 0.3$ & $0.91 \pm 0.3$ \\
J5 (5000 mg/kg) & $8.62 \pm 0.6$ & $4.81 \pm 0.2$ & $0.90 \pm 0.3$ \\
b. Saffron & & & \\
Healthy Control & $8.68 \pm 0.6^{\mathrm{b}}$ & $4.88 \pm 0.7$ & $0.85 \pm 0.1$ \\
S1 (150 mg/kg) & $8.75 \pm 0.4$ & $4.91 \pm 0.6$ & $0.84 \pm 0.2$ \\
S2 (500 mg/kg) & $8.59 \pm 0.1$ & $4.83 \pm 0.4$ & $0.89 \pm 0.3$ \\
S3 (1000 mg/kg) & $8.61 \pm 0.5$ & $4.85 \pm 0.6$ & $0.91 \pm 0.4$ \\
S4 (2000 mg/kg) & $7.74 \pm 0.7^{*}$ & $4.72 \pm 0.2^{*}$ & $0.99 \pm 0.5^{*}$ \\
S5 (5000 mg/kg) & $7.52 \pm 0.5^{*}$ & $4.59 \pm 0.4^{*}$ & $1.08 \pm 0.6^{*}$
\end{tabular}

${ }^{\mathrm{a}}$ For details of experimental conditions see the text

${ }^{b}$ Data are expressed as mean \pm SD of 8 rats in each group (In each column) * was considered significant at $P<0.05$ when compared with the healthy control group 
Table 4 Effects of herbs on liver enzymes in serum of rats

\begin{tabular}{lllll}
\hline Experimental groups $^{\mathrm{a}}$ & ALT (IU/L) & AST (IU/L) & ALP (IU/L) & LDH (IU/L) \\
\hline a. Jujube & & & & \\
Healthy Control & $81 \pm 8^{\mathrm{b}}$ & $154 \pm 11$ & $190 \pm 17$ & $354 \pm 19$ \\
J1 (150 mg/kg) & $85 \pm 6$ & $152 \pm 7$ & $191 \pm 16$ & $356 \pm 13$ \\
J2 (500 mg/kg) & $87 \pm 7$ & $156 \pm 8$ & $196 \pm 12$ & $358 \pm 19$ \\
J3 (1000 mg/kg) & $88 \pm 9$ & $158 \pm 9$ & $199 \pm 11$ & $361 \pm 12$ \\
J4 (2000 mg/kg) & $97 \pm 7^{*}$ & $167 \pm 8^{*}$ & $205 \pm 10^{*}$ & $375 \pm 19^{*}$ \\
J5 (5000 mg/kg) & $108 \pm 6^{*}$ & $188 \pm 11^{*}$ & $217 \pm 11^{*}$ & $3.86 \pm 10^{*}$ \\
b. Saffron & & & & \\
Healthy Control & $81 \pm 8^{\mathrm{b}}$ & $154 \pm 11$ & $190 \pm 17$ & $354 \pm 19$ \\
S1 (150 mg/kg) & $83 \pm 6$ & $156 \pm 7$ & $193 \pm 11$ & $353 \pm 8$ \\
S2 (500 mg/kg) & $85 \pm 9$ & $157 \pm 8$ & $196 \pm 10$ & $361 \pm 9$ \\
S3 (1000 mg/kg) & $95 \pm 7^{*}$ & $165 \pm 6^{*}$ & $208 \pm 9^{*}$ & $388 \pm 10^{*}$ \\
S4 (2000 mg/kg) & $1.08 \pm 10^{*}$ & $178 \pm 9^{*}$ & $228 \pm 11^{*}$ & $399 \pm 12^{*}$ \\
S5 (5000 mg/kg) & $1.19 \pm 11^{*}$ & $195 \pm 11^{*}$ & $242 \pm 14^{*}$ & $420 \pm 16^{*}$
\end{tabular}

${ }^{\mathrm{a}}$ For details of experimental conditions see the text

${ }^{b}$ Data are expressed as mean \pm SD of 8 rats in each group (In each column) was considered significant at $P<0.05$ when compared with the healthy control group

hepato and nephrotoxicity activities of medicinal plants including Paeonia spp [21], Polygonum multiflorum [22, 23], Teucrium polium L. (400 mg/kg; [24]), Capparis Spinosa $(400,800 \mathrm{mg} / \mathrm{kg}$; [25]), Echium amoenum $(200 \mathrm{mg} /$ kg; [26]), Melissa officinalis (1350 mg/kg; [27]) Cichorium Intybus (400 mg/kg; [28]).

Our study illustrated that all doses of Saffron and Jujube extracts did not cause mortality in treated rats. A

Table 5 Effects of herbs on kidney function

\begin{tabular}{llll}
\hline $\begin{array}{l}\text { Experimental } \\
\text { groups }^{\mathrm{a}}\end{array}$ & $\begin{array}{l}\text { BUN } \\
(\mathrm{mg} / \mathrm{dl})\end{array}$ & $\begin{array}{l}\text { Cratinine } \\
(\mathrm{mg} / \mathrm{dl})\end{array}$ & $\begin{array}{l}\text { Uric acid } \\
(\mathrm{mg} / \mathrm{dl})\end{array}$ \\
\hline $\begin{array}{l}\text { a. Jujube } \\
\text { Healthy Control }\end{array}$ & $21.61 \pm 1^{\mathrm{b}}$ & $0.53 \pm 0.06$ & $2.12 \pm 0.1$ \\
J1 $(150 \mathrm{mg} / \mathrm{kg})$ & $21.73 \pm 2$ & $0.54 \pm 0.03$ & $2.23 \pm 0.3$ \\
J2 $(500 \mathrm{mg} / \mathrm{kg})$ & $21.98 \pm 1$ & $0.53 \pm 0.07$ & $2.18 \pm 0.5$ \\
J3 $(1000 \mathrm{mg} / \mathrm{kg})$ & $22.11 \pm 2$ & $0.54 \pm 0.03$ & $2.55 \pm 0.4$ \\
J4 $(2000 \mathrm{mg} / \mathrm{kg})$ & $22.20 \pm 2$ & $0.57 \pm 0.04$ & $2.61 \pm 0.15$ \\
J5(5000 mg/kg) & $22.86 \pm 1^{*}$ & $0.61 \pm 0.07^{*}$ & $2.85 \pm 0.11^{*}$ \\
b. Saffron & & & \\
Healthy Control & $21.61 \pm 1$ & $0.53 \pm 0.06$ & $2.12 \pm 0.1$ \\
S1(150 mg/kg) & $21.58 \pm 2$ & $0.56 \pm 0.02$ & $2.25 \pm 0.3$ \\
S2 $(500 \mathrm{mg} / \mathrm{kg})$ & $21.62 \pm 1$ & $0.57 \pm 0.03$ & $2.31 \pm 0.3$ \\
S3 $(1000 \mathrm{mg} / \mathrm{kg})$ & $21.64 \pm 2$ & $0.59 \pm 0.02$ & $2.35 \pm 0.2$ \\
S4 $(2000 \mathrm{mg} / \mathrm{kg})$ & $22.46 \pm 2^{*}$ & $0.63 \pm 0.04^{*}$ & $2.91 \pm 0.4^{*}$ \\
S5 (5000 mg/kg) & $23.16 \pm 1^{*}$ & $0.72 \pm 0.08^{*}$ & $3.65 \pm 0.2^{*}$ \\
\hline
\end{tabular}

${ }^{\mathrm{a}}$ For details of experimental conditions see the text

${ }^{b}$ Data are expressed as mean \pm SD of 8 rats in each group (In each column) *was considered significant at $P<0.05$ when compared with the healthy control group significant reduction of body weight was just observed in S5-treated group $(5000 \mathrm{mg} / \mathrm{kg})$ as compared to control group $(P<0.05)$. Our data also indicated that all doses of Jujube treatments (J1-J5) and some doses of Saffron treatments (S1-S3) did not show any significant difference in some biochemical parameters such as FBS, lipid profile, total protein, albumin and total bilirubin. While two higher doses (2000 and $5000 \mathrm{mg} / \mathrm{kg}$ ) of Saffron caused a remarkable increase in the levels of total total bilirubin and decrease of total protein and albumin levels.

Usually laboratory-based criteria of liver and renal toxicities are explained by ALT and/or ALP and BUN and/ or creatinine values, respectively. The increased levels of serum AST, ALT, ALP and LDH enzymes in J4, J5, S3, S4 and S5-treated groups indicated liver dysfunction due to adverse effects of herbs in experimental rats. It may be postulated that high dosages of these extractions especially Saffron petals $(5000 \mathrm{mg} / \mathrm{kg})$ caused slight hepatotoxicity. Although previous studies did not reported jujube-induced liver injury, oral administration Saffron petals $(160,320$ and $480 \mathrm{mg} / \mathrm{kg})$ after 14 days caused the elevated liver enzymes and toxicity in liver [29]. LD50 values of saffron stigma and petal extracts (intra-peritoneal administration) in mice were 1.6 and $6 \mathrm{~g} / \mathrm{kg}$ [20]. The treatments $75,150,225$, and $450 \mathrm{mg} / \mathrm{kg}$ body weight of saffron petal extract has no significant changes in hematological parameters while the number of white blood cells in treatment groups increased [30]. Although Jujube has various medical applications including anticancer [31], this herb did not show any toxicity.

Renal insufficiency occurred with high levels of BUN, Creatinine and uric acid in treated rats with J5, S4 and S5 extractions. Whereas other treated groups showed normal levels of these factors similar control group. It is highly demanded to study the exact mechanism of these effects of Saffron and Jujube to develop their applications in clinical trials.

\section{Conclusions}

Our results clearly showed Saffron petals at 1000, 2000 and $5000 \mathrm{mg} / \mathrm{kg}$ doses were more toxic on liver and kidneys that were comparable to Jujube treatments. Further studies on improving the quality and nutritional value of this herbal mixture (Saffron petals and Jujube fruits) are recommended.

\section{Abbreviations}

ALP, Alkaline Phosphatase; ALT, Alanine Amino Teransferases; AST, Aspartate Amino Teransferases; BUN, Blood Urea Nitrogen; DLC, Leukocyte Count; FBS, Fasting Blood Suger (FBS); Hb, Hemoglobin; LDH, Lactate Dehydrogenase; PCV, Packed Cell Volume; RBC, Red Blood Cells; WBS, Total White Blood Cells.

\section{Acknowledgments}

The authors would like to thank personnel of research laboratory in Birjand University of Medical Sciences. This investigation was supported by Grant 
No. 1000 from the office of Vice Chancellor for Research, Birjand University of Medical Sciences.

\section{Authors' contributions}

$\mathrm{RH}$ designed the study, participated in data analysis and manuscript preparation. MH participated in study design and helped in manuscript preparation. BS and RE participated in experiments doing, data analysis and manuscript preparation. All authors read and approved the final manuscript.

\section{Competing interests}

Banafsheh Safizadeh, Reyhane Hoshyar, Mina Hemmati, Asghar Zarban and Roshanak Ebrahimi declare that they have no competing interests.

Received: 29 March 2016 Accepted: 29 June 2016

Published online: 18 July 2016

\section{References}

1. Rabiei Z, Rafieian-Kopaei M, Heidarian E, Saghaei E, Mokhtari S. Effects of Zizyphus jujube extract on memory and learning impairment induced by bilateral electric lesions of the nucleus Basalis of Meynert in rat. Neurochemical research. 2014:39(2):353-60.

2. Nasri H, Rafieian-kopaei M, Shirzad M, Rafieian M, Sahinfard N, Rafieian S. Effects of Allium sativum on liver enzymes and atherosclerotic risk factors. J HerbMed Pharmacol. 2013;2:23-28.

3. Hemmati M, Asghari S, Zohoori E. Effects of alcoholic and aqueous extract of Barberry, Jujube and Saffron petals on serum level of adiponectin and lipid profile in diabetic rats. Iran J Endocrinol Metab. 2015;16(5):329-37.

4. Hoshyar R, Mohaghegh Z, Torabi N, Abolghasemi A. Antitumor activity of aqueous extract of Ziziphus jujube fruit in breast cancer: an in vitro and in vivo study. Asian Pacific Journal of Reproduction. 2015:4(2):116-22.

5. Sedighi M, Rafieian-Kopaei M, Noori-Ahmadabadi M. Kelussia odoratissima Mozaffarian inhibits ileum contractions through voltage dependent and beta adrenergic receptors. Life Sci J. 2012;9(4):1033-8.

6. Rafieian-Kopaei M. Medicinal plants and the human needs. J Biol. 2011:35:635-9.

7. Bahmani M, Rafieian M, Baradaran A, Rafieian S, Rafieian-kopaei M. Nephrotoxicity and hepatotoxicity evaluation of Crocus sativus stigmas in neonates of nursing mice. Journal of Nephropathology. 2014;3(2):81-5.

8. Bathaie SZ, Hoshyar R, Miri H, Sadeghizadeh M. Anticancer effects of crocetin in both human adenocarcinoma gastric cancer cells and rat model of gastric cancer. Biochemistry and Cell Biology. 2013:91(6):397-403.

9. Hosseinzadeh $\mathrm{H}$, Motamedshariaty $\mathrm{V}$, Hadizadeh F. Antidepressant effect of kaempferol, a constituent of saffron (Crocus sativus) petal, in mice and rats. Pharmacologyonline. 2007:2:367-70

10. Omidi A, Rahdari S, Fard MH. A preliminary study on antioxidant activities of saffron petal extracts in lambs. Vet Sci Dev. 2014:4(1):1-4

11. Gao QH, Wu CS, Wang M. The jujube (Ziziphus jujuba Mill.) fruit: a review of current knowledge of fruit composition and health benefits. J Agric Food Chem. 2013;61(14):3351-63.

12. Hoshyar R, Bathaie SZ, Sadeghizadeh M. Crocin triggers the apoptosis through increasing the $\mathrm{Bax} / \mathrm{BCl}-2$ ratio and caspase activation in human gastric adenocarcinoma. AGS, cells DNA and cell biology. 2013;32(2):50-7.

13. Hoshyar R, Jamali S, Fereidouni M, Abedini MR. The cytotoxic activity of Ziziphus Jujube on cervical cancer cells: in vitro study. Cell Mol Biol. 2015; 61(8):128-30.

14. Benzie IFF, Strain JJ. The ferric reducing ability of plasma (FRAP) as a measure of antioxidant power: the FRAP assay. Anal Biochem. 1996:239:70-6.

15. Rakitzis ET. Reaction of thioureas with Folin-Ciocalteu reagent. Anal Chim Acta. 1975:78:495-7.

16. Giusti MM, Wrolstad RE. Characterization and measurement of anthocyanins by UV-visible spectroscopy. In: Wrolstad RE, Schwartz SJ, editors. Handbook of food analytical chemistry. New York: Wiley; 2005. p. 19-31 (Unit F1.2).

17. Ahmed M. Acute toxicity (Lethal Dose 50 Calculation) of herbal drug Somina in rats and mice. Pharmacol Pharm. 2015;6(3):185.

18. Mostafavinia SE, Khorashadizadeh M, Hoshyar R. Antiproliferative and proapoptotic effects of crocin combined with hyperthermia on human breast cancer cells. DNA Cell Biol. 2016. In Press.

19. Mahajan R, Chopda M. Phyto-pharmacology of Ziziphus jujuba mill- a plant review. Pharmacogn Rev. 2009;3(6):320-9.

20. Astarei Ali R, Eskandari-Torbaghan M, Abbasi-Ali Kamar R, editors. Effect of saffron (crocus sativus L.) petals on germination and primary growth of cotton (gossypium hirsutum L.). II International Symposium on Saffron Biology and Technology. 2006. p. 739.

21. Craig EA, Yan Z, Zhao QJ. The relationship between chemical-induced kidney weight increases and kidney histopathology in rats. J Appl Toxicol. 2015;35(7):729-36

22. Galloway JH, Marsh ID, Bittiner SB, Messenger AG, Gawkrodger DJ, Glet R, et al. Chinese herbs for eczema, the active compound? Lancet. 1991;337(8740):566.

23. Furukawa M, Kasajima S, Nakamura $Y$, Shouzushima M, Nagatani $N$, Takinishi A, et al. Toxic hepatitis induced by show-wu-pian, a Chinese herbal preparation. Intern Med. 2010;49(15):1537-40.

24. Mahdinia Z, Eftekhar vaghefi R, Mehrabani M, Nabipour F, Mahdinia N, Nooredin MN. The effect of petroleum ether fraction of Teucrium polium extract on laboratory mouse liver. Kerman Univ Med Sci. 2014:20(3):279-91.

25. Heidari M, Mirshamsi M, Naghibi B, Vafazade J. Evaluation of hepatotoxicity and renal toxicity of methanolic extractof Capparis Spinosa in rats. J Shahid Sadoughi Univ Med Sci. 2010;18(1):47-55.

26. Zahedi MJ, Heidari MR, Mohajeri M. Study the effect of Valeriana Officinalis and Echium Amoenum on the liver and renal function tests in rats. J Kerman Univ Med Sci. 2004;11(1):22-7.

27. Namjoo A, MirVakili M, Rafieian-Kopaei M, Faghani M. Histopatological and biochemical effects of subcute toxicity of lemon balm hydroalcoholic extract on liver and kidney tissues in the surri mice. J Shahrekord Univ Med Sci. 2013;15(4):62-72

28. Moloudi MR, Hassanzadeh K, Rouhani SH, Zandi F, Ahmadi A, Khalwatian P, et al. Effect of chloroformic extract of Cichorium intybus on liver function tests and serum level of TNF-a in obstructive cholestasis in rat. Sci J Kurdistan Univ Med Sci. 2014;19(4):10-19.

29. Karimi G, Taiebi N, Hosseinzadeh H, Shirzad F. Evaluation of subacute toxicity of aqueous extract of Crocus sativus L. stigma and petal in rats. J Med Plants. 2004;4(12):29-35.

30. Ziaee T, Razavi BM, Hosseinzadeh $\mathrm{H}$. Saffron reduced toxic effects of its constituent, safranal, in acute and subacute toxicities in rats. Jundishapur J Nat Pharm Prod. 2014:9(1):3-8

31. Abedini MR, Erfanian N, Nazem N, Jamali S, Hoshyar R. Anti-proliferative and apoptotic effects of Ziziphus Jujube on cervical and breast cancer cells. Avicenna J Phytomed. 2016;6(2):142-8.

\section{Submit your manuscript to a SpringerOpen ${ }^{\circ}$ journal and benefit from:}

- Convenient online submission

- Rigorous peer review

- Immediate publication on acceptance

- Open access: articles freely available online

- High visibility within the field

- Retaining the copyright to your article

Submit your next manuscript at $>$ springeropen.com 